\author{
LUBLIN STUDIES IN MODERN LANGUAGES AND \\ LITERATURE 41(1), 2017, HTTP://WWW.LSMLL.UMCS.LUBLIN.PL, \\ HTTP://LSMLL.JOURNALS.UMCS.PL
}

\author{
Serkan Ertin \\ Faculty of Arts and Sciences, \\ Kocaeli University \\ Kocaeli, Turkey
}

\title{
Muriel Spark's Employment of Burlesque: Parody of Detective Fiction in Not to Disturb
}

\begin{abstract}
Parody contributes to the improvement of literary genres since it is the key to various popular subgenres as in the case of the development of detective fiction. Muriel Spark's Not to Disturb, among the contemporary examples of parody of detective stories, is about a group of sinister servants in a Swiss chateu awaiting impatiently the bloody deaths of their employers, dictating memoirs and even selling the fim rights beforehand. Analysed in terms of its plot structure, characterisation and setting, the novel proves to be a brilliant example of parody of detective stories.

Keywords: parody; Muriel Spark; detective fiction; pastiche; postmodern novel
\end{abstract}

\section{Introduction}

A form of high burlesque, parody imitates the serious materials and manner of a particular literary work, or the characteristic style of a particular author, or the stylistic and other features of a serious literary form, and applies them to lowly or comically inappropriate subject (Abrams 1988: 18). For Dane, parody is "the imitative reference of 
one literary text to another, often with an implied critique of the object text" (4).

Since the early nineteenth century parody has been the most popular form of burlesque and has been applied to numerous works, authors and styles. Nonetheless, the only aim of parody, in contrast to the popular belief, is not to ridicule. Parody also contributes to improvement of literary genres. MacDonald, for instance, sees parody as the key to various popular subgenres as in the example of "the development of the popular formulaic genre known as detective fiction" (61).

Detective fiction had its Golden Age after World War I with the great authors like Agatha Christie, Dorothy L. Sayers and G. K. Chesterton. World War II brought a taste for more violence and realism to postwar writers. People became more interested in the reasons underlying crimes with the increasing emphasis on psychology. Therefore, instead of "whodunnit" tradition, which aimed at finding the criminal in the novels, "why" the crime was committed gained importance. Melling likens the function of Detective Fiction during those years, and even now, to morality or mystery plays in that in each the malefactor is discovered and punished, leading to the triumph of the good over evil in the end (9).

Despite the popularity of the genre, the first parodies, Melling says, appeared as early as one year after Sherlock Holmes stories became popular in 1891 (11). Those early examples, not surprisingly, focused on Holmes. Later on, many other characters, works, and authors of detective stories became the target of parody.

\section{Analysis}

Muriel Spark's Not to Disturb, among the contemporary examples of parody of detective stories, is about a group of sinister servants in a Swiss chateau awaiting impatiently the bloody deaths of their employers, dictating memoirs and even selling the film rights beforehand. Analysed in terms of its plot structure, characterisation, and setting, the novel proves to be a brilliant example of parody of detective stories 
Detective fiction plots follow a certain pattern. In the beginning of the story the reader is "introduced to the detective and presented with certain facts about a particular crime" (Smith 1996: 12). The crime must appear to be mysterious and uncertain, but there must be some clues. Not to Disturb, however, opens with the entrance of Lister, the butler, into the room of the servants. He introduces the theme of death in the very beginning of the novel with his quotation from John Webster's The Duchess of Malfi: "Their life, a general mist of error. Their death, a hideous storm of terror" (Spark 1974: 5). As it is revealed a few pages later, the Klopstocks and Victor Passerat are "already dead although as a matter of banal fact, the night's business has still to accomplish itself" (Spark 1974: 12). Spark keeps the mystery and tension by keeping the ambiguity between the past, present and future. When Victor Passerat arrives at the chateau, Lister says he was the first one to walk "to his death most gingerly" (Spark 1974: 11). The boundary between tenses is destroyed by Spark and the plot structure of Detective fiction is reversed. According to the pattern a detective story should start with a crime, but in this novel the reader cannot even understand whether the crime has happened or not. Moreover, no clue is given related to any possible crime in future.

The second part of the detective story is the investigation. This part, according to Smith, focuses on the detective as he examines witnesses, suspects, and clues while working toward the solution of the crime. "The investigation occupies the bulk of the plot and always leads to the solution - the climax of the story" (12). In Not to Disturb, however, the appearance of the police and a detective takes place only toward the end of the novel, when the sinister plot of the servants has been fulfilled. Everything was already planned by Lister. In the morning, he says, at eight they will "call the police and interview the journalists who will already have arrived, or be arriving. Mr. Samuel and Mr. McGuire will be in bed, but in the course of the breaking open of the library door by the police, they too will float down the staircase, surprised, and wearing their bath-robes or something seemly (Spark 1974: 64). This is exactly what happens at the end of the novel. The arrival of the police and the detective is also a part of Lister's plan 
and, therefore, of no importance in the novel. Even when the inspector comes, Lister controls them. The inspector and the police appear only for three pages in the novel; they break the library door, find the bodies of the Klopstocks and Passerat, take statements of the servants and leave the chateau (Spark 1974: 90). The inspector does not have any function in the novel and he knows much less than the servants, as seen in the example of the mad man in the attic: "'Oh yes,' says the inspector, looking up. 'We know about him. Relative of the Baroness." Lister corrects him: "“No, the Baron." (90). The servants had already learnt about the relationship of the mad man to the Baron and married Heloise to him to inherit all the property of the dead Baron. However, the detective was not aware of this, nor was he interested in learning. He was only "anxious to join his men in the police car" to leave the house (90). Thus, the investigation part of Not to Disturb does not bring the novel to its climax. The climax was the murder of the Baroness and Passerat by the Baron, and it was already known even at the beginning of the novel.

Finally, the end of the novel, in contrast to the expectations from a detective story, does not give any explanation of the crime or punishment to the villain servants. The role of the servants is not even suspected by the detective and the servants easily get away with what they did. According to Smith, however, detective stories should "emphasize the restoration of order which the detective has accomplished" in the end (12). For this reason, Not to Disturb actually reverses the plot structure of detective stories in every single aspect.

Just as the plot structure of detective stories follows a certain pattern, so does the characterisation in these works. There are certain characters taking place in each story. First there is a victim, and since the crime is usually a murder, Smith says "it's unlikely that this character will be around very long and sometimes is found in the first chapter" (12). In Not to Disturb there are two victims: the Baroness, and Victor Passerat. They both have important parts in the development of the novel, but whether the expected murder will really take place is never known until the police and the detective break the door of the library and find the bodies (Spark 1974: 88). Therefore, 
unlike those in detective stories, the victims in this particular novel live quite long.

Second, a "murderer or other criminal" is essential to develop the detective story (Melling 1996: 14). There must be someone to commit the crime. Smith claims that the criminal is usually kept in the background (13). The aim in this is to keep the suspense throughout the story. However, in Not to Disturb Spark does not seem to be trying to conceal the murderer, the Baron. However, there is a group of criminal servants who do not actively participate in the murder, but expect and look forward to the murder from the very beginning of the novel. They start to dictate memoirs and sell the film rights of the murder even before the event takes place. On the first page of the book, Eleanor, Lister's aunt, tells Heloise, the youngest maid: "Never mind him in the attic. They [the journalists]'ll be making inquiries of you. Wanting to know" (Spark 1974: 5). To inherit the property of the Baron they have already married Heloise off to the mad man in the attic, and they know pretty well that the journalists will be interested in the new Baroness, Heloise. In this way the servants keep watching the "inevitable" murder in the library and they become the partners of the Baron in the murder. However, none of the participants in the crime has been concealed by Spark, unlike in detective stories, which lends the novel a taste of parody.

Another character to be found in a detective story is a detective with or without a partner. In a classical detective story, in A. Conan Doyle and Agatha Christie for instance, the detective is the central character whose "intelligence," "eccentricity" and "aristocrat" background are essential to the plot. The detective in the classical pattern usually has a partner or confidant who is used to narrate the story (Smith 1996: 13). In Not to Disturb the detective appears for a few pages only towards the end of the story, when the plot of the servants has already worked out. The partners accompanying the detective are an inspector, two plain-clothes men, three uniformed policemen and a police photographer (Spark 1974: 88). Following the procedures, they ask a few questions none of which is unexpected or cornering for the servants: "Inspector says to Lister, 'Didn't you hear 
anything during the night? No shots? No shouting or screaming?'.....'No, Inspector. It was a wild night,' says Lister" (Spark 1974: 89). Thus, the detective and his partners are far from the solution Melling considers vital in the plot, i.e. "the good triumphant and the evil conquered and preferably punished" (16).

Finally, there are some stock characters appearing in detective stories. First, there is "the helpless young female who comes to the detective for aid" (Smith 1996: 13). She usually has a romantic interest in someone with whom she comes together with the solution of the crime. In Not to Disturb Lister alerts the police and recommends an ambulance with doctors and nurses (Spark 1974: 87). There is not a helpless young female character. Spark, using a strong wicked male character, Lister, parodies the stock character of "helpless young female".

Another stock character to be found in detective stories is the "bungling / inept policeman" used as a foil to the detective. Nonetheless, Spark does not distinguish the police or inspector from the detective.

Third, in detective stories, there is a group of false suspects, some of whom may become the second or third victims to move the plot along (Smith 1996: 14). In the novel the criminal, the Baron, is dead and the detective does not suspect the servants. Having asked a few questions, he leaves the chateau. Therefore, there is not any single suspect or other victims, and the murder seems to be completely solved. To conclude, with her different characterisation Spark parodies the characters in classical detective fiction.

The third element in fiction, the setting, has a pattern in detective stories, too. According to Smith, "the crime must occur in an isolated place" and he underlines the importance of "local colour" in setting (14). Local colour is the character types and traditions of a particular region. In Not to Disturb Switzerland is chosen by Spark as the setting. The country itself is a parody as Switzerland is a model for human rights and famous for its peace and quiet.

The entire story takes place in the chateau of the Klopstocks. It is an enclosed space in which all characters, such as the Reverend, 
Victor's friends Alex and Anne, are trapped one by one. In this way Spark achieves the sense of claustrophobia in her work, which is in accordance with classical detective stories indeed. However, this chateau is far from the gothic elements expected in a classical detective story. It was actually built only eleven years ago by the Baron and it is quite modern with its long drawing-room and large French windows. A porcelain snow-white lamb, artfully woolly, the Adam mantelpiece, the tapestried chairs, the little table, the scrolled flat desk, the porcelain vases and the walls covered with miniature portraits are all used by Spark to give the reader a taste of "the Swiss customs" (Spark 1974: 26). These items also add to the realistic quality of the setting and make it more credible.

The use of the attic is the best place to locate the mad-man story line to increase mystery and curiosity. Another successful location is that of the murder itself. As in detective stories, the murder is committed in the library behind closed doors. The Baron did not want anyone to disturb them and all the servants just waited for the "climax" to take place (Spark 1974: 29). Thus, Spark's locating the murder in the library is in full accordance with the pattern of detective stories. In this way, Spark uses a realistic setting to establish her story, and she adds local colour as well. However, she plays with the idea and parodies some elements of detective stories with her use of modern elements, which leads to a lucrative fusion of realism and fantasy.

\section{Conclusion}

As a conclusion, Not to Disturb plays with the plot structure, characterisation, and setting of classical detective stories and turns out to be a parody of the genre. It makes use of most traditional characters and some of the characteristics of setting expected in a detective story, but keeps its unique quality thanks to its reversed plot structure and modern elements.

Works Cited

Abrams, M. H. (1988). A Glossary of Literary Terms. New York: The Dryden Press. 
Dane, J. A. (1988). Parody: Critical Concepts Versus Literary Practices, Aristophanes to Sterne. London: University of Oklahoma Press.

MacDonald, J. (1997). Parody and detective fiction. Theory and Practice of Classic Detective Fiction. Jerome H. Delamater and Ruth Prigozy, eds. London: Greenwood, pp. 61-73.

Melling, J. K. (1996). Murder Done to Death: Parody and Pastiche in Detective Fiction. London: The Scarecrow.

Smith, J. R. (1996). Detective Fiction. Dubuque: Kendall/Hunt.

Spark, M. (1974). Not to Disturb. Middlesex: Penguin. 